\title{
The Hebrew of the Dead Sea Scrolls and the Tiberian Reading Tradition
}

\section{Shared Departures from the Masoretic Written Tradition}

\author{
Aaron D. Hornkohl \\ University of Cambridge, Cambridge, uK \\ adh44@cam.ac.uk
}

\begin{abstract}
The most authentic portrait of Second Temple Hebrew is afforded by the Dead Sea Scrolls, especially by those texts actually composed in Hellenistic and Roman times. On salient linguistic points Dead Sea Scrolls Hebrew agrees with the vocalization of the Tiberian reading tradition against the testimony of the written, i.e., consonantal, tradition of Masoretic Classical Biblical Hebrew material. This article presents a case study. On the one hand, these Dead Sea-Tiberian vocalization affinities are evidence of the relatively late character of their respective linguistic traditions and of the secondary character of the developments in the Tiberian reading tradition vis-à-vis the classical biblical written tradition. On the other hand, these same affinities demonstrate that the Tiberian pronunciation tradition is plausibly regarded as one that crystallized in the Second Temple Period, rather than in Byzantine or medieval times. Lastly, since joint Dead Sea-Tiberian reading departures from the classical biblical consonantal tradition constitute a tiny minority of their relevant linguistic data, most of which are characterized by historical continuity and/or linguistic heterogeneity of comparable historical depth, it is clear that the Second Temple crystallization of Dead Sea Scrolls Hebrew and the Tiberian reading tradition in no way preclude their routine preservation of authentic Iron Age features.
\end{abstract}

\section{Keywords}

Masoretic text - Tiberian tradition - reading tradition - written tradition vocalization - consonantal text 
Among textual corpora considered representative of Second Temple Hebrew, the Dead Sea Scrolls (DSs) and contemporary sources from the Judean Desert are unique from several perspectives. First, though the classical biblical material they include consists mainly of old features not especially characteristicor even uncharacteristic - of Second Temple writing and speech, sporadic anachronisms also occur. For their part, original Dss literary and documentary texts, even if sometimes written in archaizing style, are pristine witnesses of contemporary language. Second, despite the challenges of interpreting consonantal script in the absence of an oral reading tradition, the Scrolls' rather plene orthography gives at least partial indication of vocalic pronunciation, which can be compared to that of extant written and reading traditions. Finally, the Dss' secure and relatively early terminus ad quem, which entails a comparatively brief time of exposure to corruption by the hands of scribes, makes them an invaluable diachronic calibrator for the linguistic evidence found in medieval traditions, which, as products of long chains of transmission, are often suspected of having suffered the infiltration of secondary, anachronistic developments.

One corpus not normally considered representative of Second Temple Hebrew is the Tiberian biblical reading tradition, i.e., the oral realization of the Hebrew Bible preserved in vocalized manuscripts of the Masoretic textual tradition (мт). However, there are significant points of linguistic similarity between the Tiberian pronunciation tradition and Dss Hebrew (DSSH), where - and this is crucial — both differ from the linguistic reality reflected in the Tiberian written, i.e., consonantal, tradition. The implications of this situation are profound: on the one hand, both DSsH and Tiberian Biblical Hebrew (вн) exhibit features diagnostic of Second Temple Hebrew, reflecting a stage of Hebrew later than that of corresponding features in the Masoretic consonantal text. $^{2}$ On the other hand, on the basis of its affinities with DSsH, it is plausible

1 This article is a thorough revision of a paper entitled "The Historical Depth of the Tiberian Reading Tradition: With Special Reference to Second Temple Sources." I am grateful to the organizers and participants of The gth International Symposium on the Hebrew of the Dead Sea Scrolls and Ben Sira, as well as to the $D S D$ editor, editorial staff, and anonymous reviewers, for fruitful interaction.

2 The distinction between the consonantal and vocalic traditions is not clear-cut. Because no biblical manuscript in any tradition is purely consonantal, but includes some use of matres lectionis to indicate vowels, all so-called 'consonantal' texts give partial representation to vocalism. 
to regard the Tiberian pronunciation tradition as one that crystallized in the Second Temple Period, rather than in Byzantine or medieval times.

The claim that there is a degree of dissonance between the Tiberian written (consonantal) and reading (vocalization) traditions is by no means new or radical. It has long been a subject of scholarly enquiry. ${ }^{3}$ To be sure, Masoretic codices explicitly signal mismatch between the written and reading traditions. Whatever the explanation of individual cases of ketiv-qere, fundamentally, these are instances of acknowledged divergence between the written and pronunciation traditions, the latter superseding the former. ${ }^{4}$ The ketiv-qere phenomenon is relevant to the current discussion because many of these divergences involve secondary developments in the reading tradition vis-à-vis the corresponding older consonantal feature. Also, despite their secondary character, and notwithstanding the fact that the ketiv-qere mechanism is undocumented prior to medieval manuscripts, the qere forms specific to the reading tradition are clearly rooted in antiquity; i.e., they are not merely Byzantine or medieval developments. Indeed, both qere- and ketiv-type forms are routinely reflected in ancient witnesses. ${ }^{5}$ Finally —and most crucially in the present connection - the extent of divergence between the Tiberian written and reading traditions far exceeds recognized instances of ketiv-qere. Indeed, the feature discussed below manifestly involves secondary linguistic deviation from the Masoretic written tradition, but is not traditionally labeled ketiv-qere.

\section{Case Study: Formulations of the Type היים הששי versus "יום הששי "The Sixth Day"}

\subsection{The Definite Article in Noun-Adjective Constructions}

Given the norms of concord between nouns and attributive adjectives in $\mathrm{BH}-$ which ordinarily include gender, number, and definiteness - one might expect a similar situation in DSSH. And indeed, in the language of the Scrolls one

3 See Ginsberg, "Studies;" "Mi-ba'ad la-Masoret;" “Nosafot;” Kahle, The Cairo Genizah, 78-86, 100, 171-79; Barr, Comparative Philology, 207-22; "A New Look," 27, 35-36; "Migraš," esp. 31; Morag, "Ha-Masoret”; Hughes, "Post-Biblical Features”; Tov, Textual Criticism, 46-47; Joosten, "The Tiberian Vocalization"; Hendel, Steps to a New Edition, 31-32; Khan, The Tiberian Pronunciation, I:56-85; Hornkohl, "Discord."

4 For details see Khan, The Tiberian Pronunciation, I:33-55.

5 According to a preliminary count undertaken by the writer, of the 159 cases of мT ketiv-qere paralleled in DSs biblical material, 70 show at least partial agreement with the qere, 72 partial agreement with the ketiv, and in 17 cases the form agrees with neither or is ambiguous. On ketiv-qere and the ancient versions, see Gordis, Biblical Text, $55^{-66 .}$ 
encounters many examples of the expected DETERMINED NOUN + DETERMINED ADJECTIVE construction, in which both noun and attribute are explicitly determined via the definite article - ה, e.g.,

(1) הכוהן הגדול "the high priest" (11QTª $58: 18)^{6}$

(2) הברית החדשה "the new covenant" (CD 6:19)

(3) " החודש השׁ] "the s[econd] month" (4Q325 13)

(4) היום הזה "this day” (1QM 15:12).

However, one not infrequently also comes across an alternative, single-article structure in DSSH, namely, ANARTHROUS NOUN + DETERMINED ADJECTIVE, ${ }^{7}$ e.g.,

(5) "from the fountain of living water" (CD 19:34)

(6) ברית החדשה "the New Covenant” (CD 20:12)

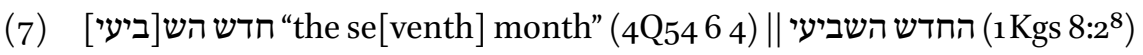

(8) "כוהן האחרון "the last priest” (4Q167 23 )

(9) מיום הזה "from that day" (11QTª 21:12).

Scholars long ago noted similar variety in Masoretic $\mathrm{BH}$, with the additional complication of apparent dissonance between the written (consonantal) and reading (vocalization) traditions. Especially in poetry, when the sequence [noun+article+adective] is preceded by a clitic preposition, e.g., כ-, ל- ל, the double-article DETERMINED NOUN + DETERMINED ADJECTIVE formulation dominates; but when the noun has no attached preposition, the construction is frequently the single-article ANARTHROUS NOUN + DETERMINED ADJECTIVE formulation. ${ }^{9}$ In non-poetic biblical texts, single-article expressions are more

6 Dss translations are from Wise, Abegg, and Cook, Dead Sea Scrolls.

7 Driver, The Judaean Scrolls, 436; Borg, "Some Observations."

8 All citations of the Hebrew Bible are from the Firkovich B 19 A Leningrad Codex as reflected in Groves' online Westminster Leningrad Codex.

9 Ley, “Über den Gebrauch;” Lambert, "L' article;” G KC § 126h; Barr, “Determination;” JM 138b. 
sporadic, and most examples are merely alternative formulations of more conventional structures. Parade examples of single-article constructions include the following:

(10) אל־חצר הפנימי (to the inner court" (Ezek 40:28)

(11) בשנת הרביעית (in the fourth year” (Jer 46:2)

(12) ב⿱ִדרך הטובה והישרה (in the good and right way” (1Sam 12:23)

However, in each of the above cases the single-article structure is either exceptional or alternates with a more conventional double-article formulation. ${ }^{10}$

\subsection{The Definite Article in $\mathrm{a}$-Ordinal Constructions}

Conspicuous from this perspective are expressions comprised of the noun "day" and an attributive ordinal. In the Tiberian biblical tradition, when this combination is preceded by a clitic preposition, it consistently comes in the symmetrical, double-article DETERMINED NOUN + DETERMINED ORDINAL formulation, e.g., ביום הששי "on the sixth day,"11 as in (13).12

(13) בַיום השביעי "on the seventh day” (Gen 2:2 [bis])

However, in eight of the ten cases in which this sort of combination has no clitic preposition, we find the alternative, asymmetrical, single-article ANARTHROUS NOUN + DETERMINED ORDINAL syntagm. These are listed in (14)-(20)..$^{13}$ For the two exceptions, see below, (23)-(24).

10 The following lists exclude cases of ambiguous consonantal forms. 1Kgs 6:36; 7:9; Ezek 10:3, 5; 40:17, 19, 28, 32; 42:1, 7, 9, 14; 43:5; 44:17 (bis), 19 (bis), 21, 27; 45:19; 46:1, 20, 21; Est 4:11; 2 Chron 20:5; single-article: 1 Kgs 7:8, 12; Ezek 40:28, 31. שנהdouble-article: Lev 25:22 (bis); 2 Kgs 18:9; Jer 25:1; Ezek 1:2; Neh 10:32; single-article: 2 Kgs 17:6; 25:1; Jer 28:1 (ketiv); 32:1 (ketiv); 46:2; 51:59; Ezra 7:8. דרך-double-article: 1 Kgs 8:36; single-article: 1 Sam 12:23. See Driver, "Linguistic Affinities," 230, n. 1 ( $\beta$ ) for further "irregular" examples.

11 Of the 126 occurrences, 125 involve - ב, one

12 Lambert, "Le mot יום"; GKC §126w; Sperber, Historical Grammar, 6o3; Barr, "Determination," 330-31; Borg, "Some Observations;" JM § 138b; Pat-El, "Semitic Definite Article," especially 35-36; Blau, Phonology and Morphology, 177-78; Moshavi and Rothstein, "Indefinite Numeral Construct Phrases," 116.

13 From the perspective of apparently parallel Modern Hebrew plural syntagms of the type ימֵי (ה)שני "Mondays," the вн single-article formulation with יום and ordinal is plausibly defined as a construct chain. Moreover, in Modern Hebrew there is a clear distinction between יום ששי "Friday" and היום הששי "the sixth day." While the вн single-article 
(14) "the sixth day" (Gen 1:31)

(15) את־יום השביעי (God blessed] the seventh day” (Gen 2:3)

(16) מיום הראשן "from the first day" (Exod 12:15a)

(17) עד־יום השבעי (until the seventh day” (Exod 12:15b)

(18) "but the seventh day” (Exod 20:10 || Deut 5:14)

(19) עד־יום השלישי "until the third day" (Lev 19:6)

(20) "and from the eighth day" (Lev 22:27)

The relationship between the two structures-the double-article expression with a clitic preposition and the single-article expression without a clitic preposition-is one of syntactic suppletion. The incongruity is blatant in cases of local discord, e.g., the three relevant cases from (13) and (15), above, presented in $(21)$ :

(21) And on the seventh day (ביום השביעי) God finished his work ... and he rested on the seventh day (בַיום השביעי) (ביוםי) ... So God blessed the seventh day יושביעי) (את־יום השביעי) (Gen 2:2-3)

Consider also (22), which presents (16) and (17) from above:

(22) On the first day (ביום הראשון) you shall remove leaven out of your houses ... from the first day (מיום הראשן) until the seventh day (עד־יום השבעי) ... (Exod 12:15)

formulation is sometimes analyzed as a construct chain-e.g., JM $§ 138 b$, where it is discussed under the heading "Apposition," but explicitly labeled "genitive" - the validity of such an analysis is open to question. Cf. והימים הראשנים "and the days that were before" (Num 6:12); לימים ראשנים “(ask now of) days that are past” (Deut 4:32); שהימים הראשנים "that the former days" (Qoh 7:10). GKC §126w treats expressions of the type יום הששים as as apposition. Borg ("Some Observations") labels it "pseudo-construct," opining that it arose as a single-article [noun+article+ordinal] expression and was only secondarily reinterpreted as a construct chain. Contextually, there is no obvious semantic difference in $\mathrm{BH}$ between no-article constructions, e.g., יום חמישי "the fifth day, Thursday" (Gen 1:23), and single-article constructions, e.g., יום הששי "the sixth day, Friday” (Gen 1:31). 
The only two consonantally unambiguous exceptions to the single-article pattern of expressions without a clitic preposition are found in Late Biblical Hebrew (LBH); ${ }^{14}$ note examples (23)-(24):

(23) מן־היום הראשון "from the first day" (Dan 10:12)

(24) ... from the first day (מן־היום הראשון) to the last day, he read from the Book of the Law of God ... and on the eighth day (ובַיום השמיני) there was a solemn assembly. (Neh 8:18)

In (24) the LBH double-article harmony both with and without a preposition stands in marked contrast to the discord between structures with and without a preposition in the Classical Biblical Hebrew (Свн) passages cited in (21)-(22); cf. also the Mishna passage cited below in (34).

Given the variety of single- and double-article constructions with nouns and attributive adjectives in the Dss, it will come as no surprise that both formulations of יום with an attributive ordinal occur there. The symmetrical, doublearticle formulation obtains in (25)-(27).

(25) וI will tell them about] the [seventh] day” (4Q216 VII 12 = Jub. 2:21)

(26) היום השביעי "the seventh day” (4Q284 2 ii 3-4)

(27) היום השׁ]ביעי (the s[eventh] day" (4Q284 32 2)

The alternative, single-article formulation is represented in (28)-(31):

(28) יום הרבביעי (Wednesday” (4Q252 I 8-9)

(29) ויום החמישי "and Thursday” (4Q252 I 9)

(30) ויום הששי "and on Friday" (4Q252 I 9-10)

יום הש]י (31) "the sec[ond] day" (4Q324d 7 ii 2)

14 As noted by Driver, "Linguistic Affinities," 229-30, n. 2. 
Excluded here are the many ambiguous syntagms in the DSs where יום has a cliticized preposition, the ambiguous phonetic realization of which makes it impossible to determine whether the construction includes one or two articles.

Having surveyed Masoretic BH and the DSs, we now consider Rabbinic (i.e., Tannaitic) Hebrew (RH). Double-article DETERMINED NOUN + DETERMINED ADJECTIVE syntax is not uncommon in Tannaitic sources, whether preceded by a clitic preposition or not. Even so, scholars consider single-article UNDETERMINED NOUN + DETERMINED ADJECTIVE syntax especially characteristic of $\mathrm{RH}^{15}$ e.g.,

(32) כנסת הגדולה (the Great Synagogue” (m. Eruv 10:10)

(33) "צv הרע "evil inclination” (m. Avot 2:11).

With specific regard to RH combinations of יום with an attributive ordinal, it is relevant that in Codex Kaufmann of the Mishna one encounters suppletion similar to that in Tiberian $\mathrm{BH}$. In most cases, the expression is preceded by a clitic preposition and vocalized with the patah of the elided definite article, resulting in a symmetrical double-article structure. However, on the three occasions when there is no clitic preposition the single-article alternative obtains. These all appear in a single passage, where the double-article alternative is also attested, highlighting the suppletion:

(34) If a man or a woman that had a flux examined themselves on the first day (בַיום הראשון) and found themselves clean, and again on the seventh day (בַיום השביעי) and found themselves clean ... R. Joshua says: They can reckon [as days of uncleanness] the first (יום הראשון) and the seventh days only. R. Akiba says:The seventh day (יום השביעי) only. (m. Niddah 10:3 $)^{16}$

Significantly, the situation in the Mishna is broadly representative of Tannaitic sources in general, where single-article structures dominate expressions without a preposition. ${ }^{17}$

15 Segal, Grammar, 180; Kutscher, A History, 130-31; Sáenz-Badillos, A History, 197; Sarfatti, "Definiteness," 161.

16 The translation is that of Danby, The Mishnah, $75^{6}$.

17 The author performed a concordance check of יום +ordinal constructions on the Ma'agarim site of the Academy of the Hebrew Language. It is worth mentioning that, like Modern 


\subsection{Scholarly Explanations}

The syntactic variety of יום+ordinal expressions displayed in Tiberian B H, DSSH, and $\mathrm{RH}$ is variously explained. Blau avers that the single-article option developed from the symmetrical double-article syntax conventional of nounattribute combinations. ${ }^{18}$ Modern Hebrew vernacular constructions such as התחנה "the central (bus) station," contrasted with normative תחנה המרכזית תמרכזית, serve as living examples of the presumed truncation, which seems to reflect a process of vernacular lexicalization, whereby the [noun+article+adjective] combination תחנה המרכזית is treated as an indivisible compound.

Pat-El argues from a broader Semitic and cross-linguistic perspective, holding that definiteness marking was first applied to attributive adjectives and only later spread to nouns, in which case single-article structures should be considered fossils representative of a linguistic phase before the double-article syntax became normative. ${ }^{19}$ Holmstedt considers the article on modifying noun phrases a subordinating particle, according to which approach its use on adjectives after anarthrous nouns is explicable in terms of the relative syntactic simplicity of the subordinate noun phrase. ${ }^{20}$

In his discussion of יום הששי and similar "pseudo-construct" expressions in ancient Hebrew and Arabic, Borg offers what might be considered a mediating position. ${ }^{21}$ Like Pat-El, he maintains that the single-article structure was inherited from early Semitic. However, Borg holds that this genuinely old Semitic structure was preserved, reanalyzed as a construct phrase, and repurposed for the lexicalization of referents from a limited range of semantic categories, namely: "spatial designations," "time orientation," "religious technical terms," and "stock phrases and designations for items of material culture." 22

\section{$2.4 \quad$ Diachrony}

Borg's analysis opens up a possibility that may help to account for the diachronic distribution of expressions of the type יום הששי and היום הששי vis-à-vis

Hebrew, BH, DSSH, and RH also present combinations of יום+ordinal with no article, e.g., יום ששי "sixth day, Friday".

18 Blau, Phonology and Morphology, 177-78.

19 Pat-El, "Semitic Definite Article," especially $35^{-36}$. See also Bar, "Determination," $330-31$.

20 More complex subordinate noun phrases employ the relativizers ששר or ש edt, The Relative Clause, $73-77$.

21 Borg, "Some Observations."

22 Driver (A Treatise, § 209) long ago noted the commonness of single-article structures "in connexion with familiar words, which were felt to be sufficiently definite in themselves without the addition of the article." See also Moshavi and Rothstein, "Indefinite Numeral Construct Phrases," 116. 
that of the broader categories of ANARTHROUS NOUN + DETERMINED ADJECTIVEand DETERMINED NOUN + DETERMINED ADJECTIVE structures: some "pseudo-construct" expressions are likely genuine vestiges that reflect a linguistic stage before the standardization of determination agreement; others are probably secondary results of lexicalization or onymization ${ }^{23}$ via compounding. ${ }^{24}$

In the case of single-article noun-ordinal expressions, the historical evidence arguably points to a genuinely old feature. Whereas unambiguous singlearticle expressions of the type יום הששי are documented in CBH, DSSH, and RH, unequivocal consonantal evidence of double-article formulations of the type is not found prior to LBH and the DSs; see (23)-(24) and (25)-(27), respectively. ${ }^{25}$

Circumstantial evidence of the Second Temple character of the Hebrew symmetrical DETERMINED NOUN + DETERMINED ORDINAL construction comes from Aramaic and Syriac. The Targumim and the Peshițta, respectively, rather consistently present double-article constructions-including, notably, in most of their renderings of the eight cases of Masoretic свн single-article formulations. Additionally, "definiteness agreement" in noun+ordinal expressions is routine in those languages outside of biblical translations, too. The fact that the LXX presents a "Hebraistic" combination of ARTICLE-NOUN + ARTICLE-ADJECTIVE in six of the eight cases of the СвH single-article syntagms is also in line with the LBH and DSs consonantal evidence for doublearticle constructions. See the table for versional evidence on the facing page.

23 Moshavi and Rothstein ("Indefinite Numeral Construct Phrases," 116, n. 54) note the possibility that certain $\mathrm{RH}$ "pseudo-constructs" were used as proper names, i.e., underwent onymization.

24 In agreement with GKC §126w, n. 9, on single-article $ם$ i'+ordinal syntax: "The omission of the article from the substantive is not to be regarded in this instance as an indication of late style, and consequently cannot be put forward as a proof of the late origin of the 'Priestly Code' ... On the other hand, the common omission of the article from the substan-

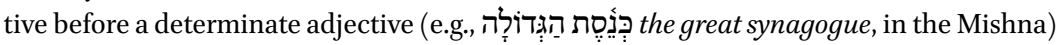
is certainly a later idiom."

25 This applies to singular expressions. The double-article plural הימים הראשנים "the former days" (Num 6:12; Qoh 7:10) is relevant (though by no means decisive) for determining the syntactic structure of single-article expressions of the type יום הששי, i.e., whether they are construct or "pseudo-construct" noun+adjective combinations, but its transparent syntax and lower susceptibility for lexicalization mean it was more likely than singular יום הראשון to submit to the norms of symmetrical determination. In sum, whether in CBH, LBH, DSSH, or RH, there is nothing unconventional about double-article plural הימים הראשנים, whereas, according to consonantal evidence, double-article singular היום הראשום is characteristic only of post-exilic material. 


\begin{tabular}{|c|c|c|c|c|}
\hline Reference & $\mathbf{M T}=\mathbf{S P}$ & Targum Onqelos & Peshițta & $\mathbf{L X X}$ \\
\hline Gen 1:31 & יום הששי & יום שתיתי & 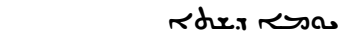 & 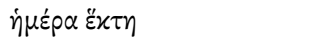 \\
\hline Gen 2:3 & את יום השביעי & ית יומא שביעאה & لנهת צכהריה & $\tau \dot{\eta} \nu \dot{\eta} \mu \varepsilon \dot{\varepsilon} \rho \alpha \nu \tau \dot{\eta} \nu \dot{\varepsilon}^{\prime} \beta \delta \delta \dot{\mu \eta} \nu$ \\
\hline Exod 12:15a & מיום הראישון & מיומא קדמאה & נדم مدهת م.دדبم & 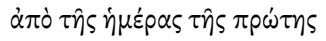 \\
\hline Exod 12:15b & ועד יום השביעי & עד יומא שביעאה & 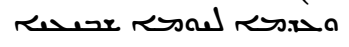 & 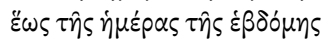 \\
\hline Exod 20:10 & 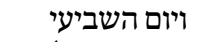 & ויומא שביעאה & 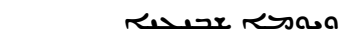 & $\tau \hat{\eta} \delta \dot{\varepsilon} \dot{\eta} \mu \varepsilon \dot{\varepsilon} \rho \alpha \underline{\imath} \tau \hat{\eta} \dot{\varepsilon} \delta \delta o ́ \mu \eta$ \\
\hline Lev 19:6 & עד יום השלישי & עד יומא תליתאה & rdudix rad & 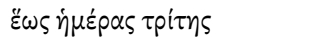 \\
\hline Lev 22:27 & 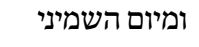 & ומיומא תמינאה & 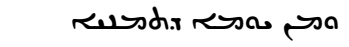 & $\tau \hat{\eta} \delta \dot{\varepsilon} \eta \dot{\eta} \mu \dot{\varepsilon} \rho \alpha \underline{\imath} \tau \hat{\eta} \partial \gamma \delta \delta$ \\
\hline Deut 5:14 & 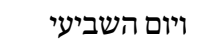 & ויומא שביעאה & 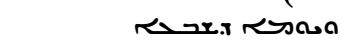 & 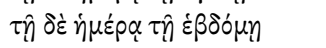 \\
\hline
\end{tabular}

While there was sufficient internal analogical pressure for the development of double-article היום הששי הששי from single-article, one might also speculate that convergence with Aramaic contributed to the process.

The trajectory of LBH and DSSH היום הששי expressions does not continue into RH. In other words, judging from the extant data, double-article יום +ordinal constructions without prepositions came and went from ancient Hebrew in the Second Temple Period. Their failure to take hold in $\mathrm{RH}$ was probably due to a combination of factors: their rarity in $\mathrm{BH}$; the prestige of the Pentateuchal passages in which the alternative structure appears; the fact that in RH יום+ordinal expressions often feature in the conservative and formulaic context of prayers and blessings; the fertile ground for the preservation of single-article expressions afforded by RH's apparent openness to lexicalized pseudo-constructs. Whatever the reason, the simple fact is that the suppletive Tiberian вн situation of יום השיום הששי without clitic prepositions and clitic prepositions is also characteristic of $\mathrm{RH}$ (though one may question the authenticity of the double-article vocalization in the latter).

\subsection{Dissonance within the Traditions: A Call for a Nuanced Approach}

We are now positioned to consider the matter of dissonance between Masoretic BH, DSSH, and RH consonantal evidence for single-article יום הששי forבַיום הששי mulations and the consistent Tiberian double-article vocalization in constructions with clitic prepositions, as well as its implications for Dss cases of and the like. The recognition of dissonance is not new. ${ }^{26}$ It is commonly hypothesized that the consistent double-article syntax of expressions of the type בַיום הששי in the Tiberian reading tradition is due to secondary recast-

26 Lambert, "Le mot יום;" GKC §126h; Sperber, Historical Grammar, 6o3; Barr, "Determination," 310-12, 325-33; Borg, "Some Observations," 31, 33; JM § $138 \mathrm{~b}$. 
ing in line with standard BH noun-adjective concord, which would presumably also be responsible for the unequivocal DSs and LBH consonantal evidence for double-article יום+ordinal structures. In his discussion of terms for "time orientation," Borg speculates: "given the secondary origin of the vowellings of this particle in the Masoretic text, all the examples cited from the Dss stand a good chance of being genuine pseudo-constructs."27 In other words, despite unambiguous LBH and DSs double-article expressions of the type היום הששי, בַיום הששי Borg takes for granted the uniformly secondary character of Tiberian realizations and reasons that DSs expressions with prepositions were similarly single-article constructions. Of course, this assumption renders the Tiberian double-article vocalization with prepositions entirely anachronistic.

The adoption of such a sweeping, one-size-fits-all interpretation of DSSH -יו-ordinal constructions with clitic prepositions as cases of ANARTHROUS NOUN + DETERMINED ADJECTIVE/ORDINAL syntax is premature and unwarranted. The fact that both $\mathrm{LBH}$ and DSSH document cases of double-article structures without clitic prepositions means that at least some proportion of their cases with clitic prepositions may plausibly be interpreted as accurately reflecting double-article syntax. There seems no reason to doubt the ביום authenticity of double-determination in every case of Tiberian and Dss and similar. Arguably, any charge of anachronism would apply only to double-article vocalizations in СвH texts, where no unambiguous consonantal evidence of the double-article construction without a clitic preposition.

But the validity of even this less sweeping portrayal is questionable. Admittedly, the uniform Tiberian double-article vocalization בַיום הששי is almost certainly evidence of secondary development; likewise the Свн mix in close proximity of double- and single-article structures, respectively, with and without clitic prepositions. Beyond this, though, it is difficult to be sure of much. One problem is that, in the nature of things, formulations with clitic prepositions account for 126 of 136 biblical cases. The mere ten tokens without a clitic preposition are a meager sample on which to base diachronic conclusions. The general point is perhaps best made in Barr's well-reasoned treatment of alleged differences between the Tiberian written and reading traditions involving representation of the definite article in poetry, which is here quoted at some length:

[A]lthough we cannot assume that every 'article' marked upon a preposition $b, k$, or $l$ in early poetry was 'really' there, it is unwise scepticism to suppose that none of them were really there or that only those marked 
with the consonantal $h$ can be taken as actual ... Though the reading tradition was not always 'right', this is not an adequate reason for supposing that in this respect it was always wrong ...

$[\mathrm{T}]$ he rules and practices of use of the article, even in the central biblical period, were more fluid, varied and illogical than traditional explanation has suggested. The use of the article was in a process of change during - perhaps one should even say 'throughout' - the biblical period; and I have said nothing of the post-biblical usage, which certainly deserves to be taken into consideration here as well. This could mean that some of the reconstitution of patterns in the later reading tradition was in continuity with processes that were taking place during biblical times; it could even mean that some of this reconstitution was already under way within the formation of the Bible. ${ }^{28}$

We know on the basis of consonantal evidence that the double-article היום הששי הas an option in ancient Hebrew by Second Temple times, at the latest. A lack of evidence precludes establishing whether it existed before that. While the consideration is entirely conjectural, conceivably, given a larger sample size of Свн cases without clitic prepositions, sporadic СвH cases of היום הששי might have occurred. And irrespective of this eventuality, one can imagine a scenario in which doubly-determined בַיום הששי developed without doublearticle היום הששי ever having enjoyed widespread currency. Indeed, evidently, this is exactly what transpired, since double-article היום השש is only very rarely attested in any phase of ancient Hebrew. But why must the development of such suppletive syntax be considered a post-biblical phenomenon? Is there any reason to discount the possibility that it could have taken hold in LBH, or even свн? Indeed, it is not unthinkable that doubly-determined expressions with clitic prepositions, like בַיום הששי, preceded and influenced the development of doubly-determined cases without clitic prepositions, like היום הששי. It is entirely possible that Iron Age Hebrew knew a double-article structure like Tiberian יביום הששי, and that this coexisted with single-article יום הששי, in which case the Tiberian reading tradition merely standardized the double marking. In any case, it is dubious to argue on the basis of just eight свн single-article preserves a historically authentic double-article vocalization. And if any are historical, then only a portion of Tiberian בַיום הששי and similar is secondary. Likewise, in the DSS any number of cases of ביום הששי could be variously double- or single-article constructions. 


\section{$3 \quad$ Conclusion}

The feature discussed in this study is one of many on which DSSH and the Tiberian reading tradition jointly deviate from an apparently older alternative in the Masoretic свн written tradition. While such deviations demonstrate a degree of anachronism in the Tiberian pronunciation tradition vis-à-vis the Masoretic written tradition, linguistic affinity with the Dss confirms the plausibility of the Second Temple crystallization of the Tiberian reading tradition. The uniformity of the Tiberian vocalization where it disagrees with the written tradition, including consistent double-article בַיום הששי vocalization, is reasonably explained only as a secondary development. However, since departures from the Masoretic CBH written tradition common to both DSSH and the Tiberian pronunciation tradition are regularly attested in Masoretic LBH consonantal material, it emerges that even the relevant secondary developments manifest remarkable historical depth. Indeed, some features of this type are evidenced in свн consonantal material and/or Iron Age epigraphy. ${ }^{29}$ Their dominance in the Tiberian reading tradition may well be secondary, but it seems to have resulted from standardization born of the expanded use of genuinely old minority forms in accord with late conventions. Finally, secondary features comprise just a small portion of DSSH and of the Tiberian reading tradition. The fact that such features are often anticipated in Persian Period and Iron Age sources has profound implications for assessing the historical authenticity of the remaining majority of features that comprise these corpora's respective linguistic profiles, to which no suspicion of anachronism attaches.

\section{Bibliography}

Barr, James. Comparative Philology and the Text of the Old Testament, with Additions and Corrections. Winona Lake: Eisenbrauns, 1987.

Barr, James. "A New Look at Kethibh-Qere." os 21 (1981): 19-37.

Barr, James. "Migraš in the Old Testament." Jss 29 (1984): 15-31.

Barr, James. “'Determination' and the Definite Article in Biblical Hebrew.” Jss 34 (1989): 307-33.

29 There are many such features, among them the recasting of I- $y$ weqatal forms as we-yiqtol forms (Joosten, "Textual Developments," 30-33), univerbalization of the infinitive construct with the preposition - ל- (Hornkohl, Discord, 230-57), vowel-final $2 \mathrm{~ms}$ verbal and pronominal endings (idem, 261-62), and $-\bar{a} v$ realization of the 3 ms suffix (idem, 257-73). 
Blau, Joshua. Phonology and Morphology of Biblical Hebrew: An Introduction. LSAws 2. Winona Lake: Eisenbrauns, 2010.

Borg, Alexander. "Some Observations on the יום הששי Syndrome on the Hebrew of the Dead Sea Scrolls." Pages 26-39 in Diggers at the Well. Edited by Takamitsu Muraoka and John F. Elwolde. STDJ 36. Leiden: Brill, 2000.

Danby, Herbert. The Mishnah. Oxford: Clarendon, 1933.

Driver, Godfrey R. The Judaean Scrolls: The Problem and a Solution. Oxford: Blackwell, 1965.

Driver, Samuel R. "On Some Alleged Linguistic Affinities of the Elohist." Journal of Philology 11 (1882): 201-36.

Driver, Samuel R. A Treatise on the Use of the Tenses in Hebrew: And Some Other Syntactical Questions. 3rd edition. Oxford: Clarendon, 1892.

Ginsberg, Harold L. "Studies on the Biblical Hebrew Verb." AJSLL 46 (1929): 5358.

Ginsberg, Harold L. "From behind the Massorah." Tarbiz 5 (1934): 208-23 [Hebrew].

Ginsberg, Harold L. “Addenda to 'From behind the Massorah' (Tarbiz V, 208-23).” Tarbiz 7 (1936): 543 [Hebrew].

G KC = Gesenius, Wilhelm, Emil Kautsch, and Arthur E. Cowley. Gesenius' Hebrew Grammar. 2nd English edition. Oxford: Clarendon, 1910.

Gordis, Robert. The Biblical Text in the Making: A Study of the Kethib-qere. New York: Ktav, 1971.

Groves, J. Alan, and Dale Wheeler. Westminster Theological Seminary Hebrew Morphology

Database, version 4.45. Glenside: J. Alan Groves Center for Advanced Biblical Research, 1991-2010.

Hendel, Ronald. Steps to a New Edition of the Hebrew Bible. TCs 10. Atlanta: SB L Press, 2016.

Holmstedt, Robert D. The Relative Clause in Biblical Hebrew. LsAws 10. Winona Lake: Eisenbrauns, 2016.

Hornkohl, Aaron D. "Discord between the Tiberian Written and Reading Traditions: Two Case Studies." Pages 227-8o in Studies in Semitic Vocalisation and Reading Traditions. Edited by Aaron D. Hornkohl and Geoffrey Khan. csLC 3. Cambridge: University of Cambridge and Open Book Publishers, 2020.

Hughes, Jeremy. "Post-Biblical Features of Biblical Hebrew Vocalization." Pages 67-80 in Language, Theology, and the Bible: Essays in Honour ofJames Barr. Edited by Samuel E. Balentine and John Barton. Oxford: Clarendon, 1994.

JM = Joüon, Paul and Takamitsu Muraoka. A Grammar of Biblical Hebrew. s B 27. Rome: Pontifical Biblical Institute, 2006.

Joosten, Jan. "The Tiberian Vocalization and the Hebrew of the Second Temple Period." Pages 25-36 in Hebrew of the Late Second Temple Period: Proceedings of a Sixth Inter- 
national Symposium on the Hebrew of the Dead Sea Scrolls and Ben Sira. Edited by Eibert Tigchelaar and Pierre Van Hecke. STDJ 114. Leiden: Brill, 2015.

Kahle, Paul. The Cairo Geniza. Oxford: Blackwell, 1959.

Khan, Geoffrey. The Tiberian Pronunciation Tradition of Biblical Hebrew. 2 vols. CSLC 1. Cambridge: University of Cambridge and Open Book Publishers, 2020.

Kutscher, Eduard Y. A History of the Hebrew Language. Leiden: Brill and Jerusalem: Magnes, 1982.

Lambert, Mayer. "Le mot יום suivi des nombres ordinaux." RÉJ 31 (1895): 279-81.

Lambert, Mayer. "L' article dans la poésie hébräique." RÉJ 37 (1898): 203-209.

Ley, Julius. "Über den Gebrauch des Artikels in der rhythmischen Poesie der Hebräer." Neue Jahrbücher für Philologie und Paedagogik 144 (1891): 341-51.

Morag, Shelomo. "Ha-Masoret ha-Ṭavranit šel Lešon ha-Miqra: Homogeniyut veHețerogeniyut.” Peraqim: Sefer ha-Šana šel Meǩon Šoqen (1974): 105-44.

Moshavi, Adina, and Susan Rothstein. "Indefinite Numerical Construct Phrases in Biblical Hebrew." Jss 63 (2018): 99-123.

Pat-El, Na'ama. "The Development of the Semitic Definite Article: A Syntactic Approach." JSS 54 (2009):19-50.

Sáenz-Badillos, Angel. A History of the Hebrew Language. Translated by John F. Elwolde. Cambridge: Cambridge University Press, 1993.

Sarfatti, Gad Ben Ami. "Definiteness in Noun-Adjective Phrases in Rabbinic Hebrew." Pages 153-67 in Studies in the Hebrew Language and the Talumdic Literature. Edited by Menachem Z. Kaddari and Shimon Sharvit. Ramat-Gan: Bar-Ilan University Press, 1989.

Segal, Moshe. A Grammar of Mishnaic Hebrew. Oxford: Clarendon, 1927.

Sperber, Alexander. A Historical Grammar of Biblical Hebrew: A Presentation of Problems with Suggestions to Their Solution. Leiden: Brill, 1966.

Tov, Emanuel. Textual Criticism of the Hebrew Bible. 3rd ed. Minneapolis: Fortress, 2012. Wise, Michael O., Martin G. Abegg, Jr., and Edward M. Cook. The Dead Sea Scrolls: A New Translation. San Francisco: Harper, 2005. 